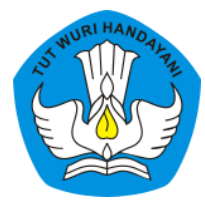

Page: $421-442$

\title{
PENGGUNAAN CANVA PADA PEMBELAJARAN BERBASIS PROYEK UNTUK MENINGKATKAN KETERAMPILAN DAN MOTIVASI MENULIS SISWA
}

\author{
Siswanjaya \\ Sekolah Menengah Pertama Negeri 1 Terbanggi Besar, Lampung Tengah, Indonesia \\ Contributor Email: siswanjaya@gmail.com
}

Received: Feb 9, 2021

Accepted: Mar 7, 2021

Published: Jul 30, 2021

Article Url: https://ojsdikdas.kemdikbud.go.id/index.php/didaktika/article/view/259

\begin{abstract}
Motivation and writing skill become interesting issue to know by all teachers. One of the writing assignments for eighth graders is writing greeting card. This study was aimed to examine whether the implementing of project-based learning and the use of Canva can improve students' motivation and writing skills. The subject of this Classroom Action Research (CAR) was 30 students of class VIIIE of SMPN I Terbanggi Besar in the academic year 2019/2020 consisting 10 males and 20 females. Data collecting techniques were conducted by giving questionnaire to know the students' motivation and writing project to know the students' writing skill. This study conducted in two cycles. The finding of cycle I and cycle II show that the students' score for motivation and writing aspects was increase. The mean score for the the student's motivation was 59,9 in preliminary study, 74,1 in cycle I and 84,9 in cycle II. The mean score for students' writing was 56,7 in preliminary study, 69,3 in cycle I and 79,6 in cycle II. It can be concluded that the implementing of projectbased learning and the use of Canva can improve students' motivation and writing skill.
\end{abstract}

Keywords: Writing; Canva; Project Based Learning 


\begin{abstract}
Abstrak
Motivasi dan keterampilan menulis menjadi hal yang menarik untuk diketahui oleh semua guru. Salah satu tugas menulis untuk siswa kelas delapan adalah menulis kartu ucapan. Penelitian ini bertujuan untuk menguji apakah penggunaan Canva dalam pembelajaran berbasis proyek dapat meningkatkan motivasi dan keterampilan menulis siswa. Subjek Penelitian Tindakan Kelas (PTK) ini adalah 30 siswa kelas VIIIE di SMPN I Terbanggi Besar tahun pelajaran 2019/2020 yang terdiri dari 10 laki-laki dan 20 perempuan. Teknik pengumpulan data dilakukan dengan memberikan angket untuk mengetahui motivasi siswa dan tugas menulis untuk mengetahui keterampilan menulis siswa. Penelitian ini dilakukan dalam dua siklus. Temuan pada siklus I dan siklus II menunjukkan bahwa nilai siswa untuk aspek motivasi dan menulis meningkat. Nilai rata-rata untuk tingkat motivasi siswa adalah 59,9 pada penelitian pendahuluan, 74,1 pada siklus I dan 84,9 pada siklus II. Nilai rata-rata menulis siswa adalah 56,7 pada penelitian pendahuluan, 69,3 pada siklus I dan 79,6 pada siklus II. Dapat disimpulkan bahwa pengunaan canva pada pembelajaran berbasis projek dapat meningkatkan keterampilan dan motivasi menulis siswa.
\end{abstract}

Kata Kunci: Menulis; Canva; Pembelajaran Berbasis Proyek

\title{
A. Pendahuluan
}

Salah satu keterampilan berbahasa Inggris yang penting adalah menulis. Menulis memberi sebuah kesempatan bagi siswa untuk menyampaikan ide atau pendapat, saran, perasaan, maupun pemikiran kepada pembacanya. Harmer (2001) mengatakan menulis adalah bentuk komunikasi untuk menyampaikan pemikiran atau mengekspresikan pemikiran melalui bentuk tulisan. Nunan (2003: 88) juga mengatakan menulis adalah karya mental untuk menemukan ide, berpikir tentang bagaimana berkomunikasi dan mengembangkannya menjadi pernyataanpernyataan dan paragraf-paragraf yang jelas bagi pembaca. Kegiatan menulis juga memberikan kesempatan kepada siswa untuk mempraktikkan bagaimana mengunakan bahasa Inggris yang telah mereka pelajari. Siswa dapat menerapkan langsung teori-teori pembelajaran bahasa dengan tepat pada tulisan mereka. Hal ini sejalan dengan yang telah diungkapkan oleh Harmer (2004) yang mengatakan 
bahwa menulis mendorong siswa untuk fokus pada penggunaan bahasa yang akurat.

Tujuan seseorang menulis akan disampaikan melalui tulisannya kepada pembacanya. Tujuan menulis menurut Grenville (2001: 1) ada tiga yaitu mengibur, memberi informasi, dan memengaruhi atau membujuk pembaca. Ini hampir sama dengan yang disampaikan Tarigan (2008: 24) bahwa tujuan menulis adalah menghibur atau menyenangkan, memberitahukan atau mengajar, mengutarakan atau mengekspresikan emosi, serta meyakinkan atau mendesak.

Jenis-jenis kegiatan menulis sangatlah bervariasi. Brown (2015) menyatakan bahwa ada lima jenis kegiatan menulis. Jenis kegiatan menulis yang pertama adalah menyalin (imitative atau mechanical learning). Ini adalah kegiatan menulis level awal di mana siswa belajar untuk menulis dengan sederhana huruf, kata, ataupun kalimat-kalimat pendek dengan tujuan untuk mempelajari aturan yang berhubungan dengan ejaan. Jenis kegiatan menulis yang kedua adalah intensive atau controlled writing. Ini adalah kegiatan menulis di mana siswa memproduksi kosa kata yang tepat dalam suatu konteks, atau mampu menunjukkan keterampilan menggunakan tata bahasa. Contoh kegiatannya adalah menuliskan kembali paragraf yang sudah dibacakan oleh guru atau dapat juga meminta siswa menuliskan sebuah cerita dengan memberikan pertanyaan-pertanyaan penuntun setelah siswa menonton videonya. Kegiatan menulis yang ketiga adalah menulis mandiri (self writing). Dalam kegiatan menulis ini siswa menuliskan dengan hanya dirinya sendiri sebagai audience. Contoh kegiatan menulis ini adalah menulis pada buku harian atau mencatat materi dari guru. Kegiatan menulis yang ke empat adalah menulis ilmiah (display writing). Dalam kegiatan menulis ini siswa mengerjakan latihan-latihan dengan jawaban-jawaban singkat, menulis esai ataupun menulis laporan penelitian. Kegiatan menulis yang kelima adalah menulis otentik (real writing). Tujuan kegiatan menulis ini adalah benar-benar untuk mengomunikasikan pesan yang diinginkan 
kepada pembaca. Contoh kegiatannya adalah menulis informasi ilmiah, menulis surat, mengisi blanko ataupun menulis pada kartu pos.

Menurut penjelasan di atas, kegiatan menulis kartu ucapan pada siswa kelas delapan dapat dikategorikan pada kegiatan menulis otentik. (real writing). Pada kegiatan menulis ini siswa benar-benar mengomunikasikan pesan yang ditulisnya pada kartu ucapan yang ditujukan pada pembaca.

Kegiatan menulis yang baik akan melalui beberapa tahapan. Ini dimaksudkan agar tulisan yang dihasilkan benar-benar sesuai yang diharapkan dan maksud tulisan akan sampai kepada pembacanya dengan tepat. Harmer (2004) mengatakan seorang penulis akan melalui tahap perencanaan (planning), menulis draft (drafting), mengedit tulisan (editing), dan menulis draft terakhir (final version). Brown (2015) dengan mengadaptasi dari Weigle (2014) menyatakan bahwa kegiatan menulis diawali dengan prapenulisan (prewriting) berupa kegiatan awal sebelum menulis seperti menonton video, diskusi, membaca dan lain-lain. Setelah itu dilanjutkan dengan menulis draft awal, kemudian pemberian komentar terhadap tulisan awal, menulis draft kedua, pemberian komentar atau pengoreksian tulisan dari pihak lain, dan yang terakhir adalah penulisan draft akhir.

Kegiatan menulis untuk siswa SMP kelas delapan tidak hanya sebuah kegiatan yang berorientasi pada hasil akhir, tetapi seharusnya juga menjadi kegiatan yang prosesnya menyenangkan bagi siswa. Ternyata menulis dalam bahasa Inggris bukanlah hal yang mudah bagi sebagian siswa Sekolah Menengah Pertama (SMP). Apalagi sebagian besar dari mereka banyak yang baru belajar bahasa Inggris di level SMP. Menulis menjadi salah satu kegiatan yang mungkin dipandang membosankan, sulit dan tidak menarik. Siswa dituntut mengerti kata-kata, tata bahasa dan lain sebagainya. Hal ini persis seperti yang dikatakan Raimes (1983) bahwa menulis tidaklah semudah berbicara atau meletakkan kata-kata diatas kertas. Secara umum seorang penulis harus memahami standar 
bentuk grammar, kosakata dan syntax. Selain itu, mereka juga harus mengerti penggunaan tanda baca, dan ejaannya. Ini adalah proses yang mebutuhkan waktu, tidak dapat dilakukan secara spontan.

Menurut kurikulum 2013 (K13) untuk Sekolah Menengah Pertama, salah satu kegiatan menulis dalam Bahasa Inggris ditujukan bagi siswa kelas delapan pada semester ganjil. Pada silabus tercantum bahwa salah satu kegiatan menulis untuk siswa kelas delapan adalah menulis kartu ucapan.

Menulis kartu ucapan tidak hanya membutuhkan keterampilan menulis saja tetapi kegiatan ini seharusnya menjadi suatu kegiatan yang menyenangkan bagi siswa dalam hal mendesain kartu tersebut agar tampak cantik dan menarik hasilnya. Hal ini dapat menumbuhkan motivasi belajar bagi siswa. Namun masih banyak siswa yang menganggap kegiatan ini hanyalah menyelesaikan tugas untuk dikumpulkan kepada guru untuk dinilai.

Keterampilan menulis siswa yang baik biasanya sejalan dengan motivasi siswa yang baik pula dimana motivasi menjadi salah satu faktor bagaimana siswa berusaha dengan gigih memahami apa yang sedang dipelajarinya. Menurut Sumiati \& Azra Menurut Sumiati \& Asra (2007: 59) dalam Hidayat, R.W (2020) motivasi pada dasarnya adalah dorongan adalah dorongan dari dalam diri yang muncul untuk melakukan sesuatu sehingga munculnya perilaku dalam belajar. Hamalik (2008) mengatakan bahwa ada dua komponen motivasi yaitu yaitu: komponen dalam (inner component) dan komponen luar (outer component). Komponen dalam ialah perubahan dalam diri seseorang, keadaan merasa tidak puas dan ketegangan psikologis. Komponen luar ialah apa yang diinginkan seseorang, tujuan yang menjadi arah kelakuannya. Berdasarkan definisi tersebut, komponen dalam ialah kebutuhan-kebutuhan yang ingin dipuaskan, sedangkan komponen luar ialah tujuan yang hendak dicapai. Sementara Dimyati dan Mudjiono (2009) menyatakan ada tiga komponen dalam motivasi yaitu kebutuhan yang ia harapkan, dorongan untuk mencapai harapan dan tujuan yang mengarahkan prilaku, dalam hal ini 
adalah prilaku belajar. Motivasi terdiri dari dua jenis yaitu motivasi dari dalam diri seseorang (intrinsik) dan motivasi dari luar diri seseorang (ektrinsik) dimana motivasi adalah hal yang bisa berubah-ubah setiap waktu.

Berdasarkan pengalaman peneliti yang telah mengajar selama 11 tahun di SMPN I Terbanggi Besar, kegiatan menulis kartu ucapan tidak ditindaklanjuti dengan kegiatan lainnya yang bermakna. Guru-guru Bahasa Inggris hanya mengumpulkan tugas yang telah dibuat siswa dan memberi nilai. Hasil tugas menulis kartu ucapan siswa kelas VIIIE pada semester ganjil tahun pelajaran 2019-2020 menunjukkan bahwa kartu ucapan yang dibuat oleh siswa masih minim dengan ucapan atau ungkapan, terjadi beberapa kesalahan menulis kosakata, frasea ataupun struktur kalimat. Beberapa siswa masih salah dalam penggunaan kata ganti dan kata hubung. Seluruh siswa juga masih membuat kartu ucapan secara konvensional dengan minim sekali desain. Guru telah menyampaikan kepada siswa untuk dapat membuat kartu ucapan baik manual maupun secara digital tetapi hampir sebagian besar siswa membuatnya secara manual.

Dari hasil kuesioner yang diisi oleh siswa-siswa juga terlihat bahwa cara mengajar guru tidak membuat mereka termotivasi sehingga mereka menganggap bahwa menulis kartu ucapan bukanlah suatu kegiatan yang menarik. Siswa-siswa juga mengakui mengalami keterbatasan dalam pemilihan kosakata maupun ide dalam menulis kartu ucapan.

Berdasarkan analisis permasalahan-permasalahan di atas, peneliti menerapkan pendekatan pembelajaran berbasis proyek (Project Based Learning) dan penggunaan aplikasi Canva dalam penulisan kartu ucapan secara digital.

Peneliti memilih Project Based Learning ( $\mathrm{PjBl}$ ) sebagai strategi pembelajaran yang diharapkan dapat menyelesaikan masalah pembelajaran siswa salah satunya yaitu tentang motivasi siswa. Blumenfeld, et al (1991) proyek bisa meningkatkan ketertarikan siswa karena melibatkan siswa dalam menyelesaikan masalah-masalah otentik 
dalam bekerja bersama dengan yang lainnya dan dalam membangun solusi yang sebenarnya. Ketertarikan siswa dalam kegiatan belajar mengajar menjadi salah satu faktor meningkatnya motivasi. Larmer (2015) juga menyatakan bahwa PjBL adalah sebuah metode pengajaran yang sangat kuat, salah satunya adalah untuk memotivasi siswa dalam mengikuti kegiatan pembelajaran.

Selain menerapkan PjBL peneliti juga memilih Canva sebagai media siswa dalam membuat kartu ucapan secara digital. Canva memiliki tampilan (interface) yang sederhana namun lengkap. Siswa dapat mempelajari contoh-contoh kartu ucapan yang ada di Canva sehingga memperkaya pengetahuan siswa berupa kosakata, istilah atau ungkapan yang berhubungan dengan kartu ucapan. Ketika mengunakan Canva siswa tinggal drag and drop (seret dan taruh) di mana telah tersedia bermacam template dan font yang siap digunakan. Peneliti percaya hal ini juga dapat membuat hasil tulisan siswa lebih baik dan tingkat ketertarikan dalam menyelesaikan proyek yang ditugaskan juga meningkat.

Canva juga menawarkan kelebihan lain yaitu hasil desain kartu ucapan siswa dapat diunduh langsung dalam berbagai format yaitu JPG, PNG, dan PDF atau disimpan langsung pada web Canva dan dapat dishare langsung melalui media sosial. Kelebihan ini memungkinkan siswa untuk mengumpulkan tugas langsung kepada guru mengingat saat ini kita berada di era digitalisasi pendidikan. Smaldino, dkk. (2015) menyatakan bahwa visual media, salah satunya Canva memberikan banyak kelebihan seperti membuat ide-ide abstrak menjadi nyata, memotivasi siswa, memberi perhatian langsung, mengulangi informasi, mengingat kembali pengetahuan sebelumnya dan menyederhanakan upaya belajar.

Pengimplementasian PjBL dan Canva merupakan pilihan yang tepat pada era digital saat ini saat kartu-kartu ucapan manual sudah mulai ditinggalkan dan beralih pada kartu ucapan digital yang disampaikan melalui media-media sosial. Ini adalah bagian guru untuk memasukkan 
teknologi ke dalam pendidikan. Blumenfeld, et al (1991) mengatakan bahwa peranan yang sangat kuat dalam meningkatkan motivasi siswa dan guru untuk melakukan dan merepkan suatu proyek adalah melalui teknologi.

Wibowo, Y.P \& Aji, K.R (2017) dalam hasil penelitiannya yang berjudul Using Project Based Learning to Improve Students Writing on Greeting Card menemukan bahwa terjadi peningkatan kemampuan siswa dalam menulis kartu ucapan dalam hal kreativitas dan mendesain kartu ucapan. Pratomo (2014) yang berjudul The Use of Project-Based Learning to Improve the Students' Writing Skills at Class VII F of SMP Negeri 7 Magelang in the Academic Year Of 2013/2014 menyatakan bahwa terjadi peningkatan pada aspek content, organization, grammar, vocabulary dan mechanic dalam menulis. Hardiyanto (2019) dalam penelitiannya yang berjudul The Implementation of Project-Based Learning in Teaching Writing of Factual Report Texts menunjukkan hasil yang positif dalam kegiatan menulis yang ditujukan pada siswa kelas 9.1 SMPN 2 Bandar Lampung. Terjadi respon yang baik pada setiap tahapan PjBL yang dilalui siswa dalam pembelajaran.

Tujuan penelitian ini adalah untuk mengetahui seberapa efektif penerapan pembelajaran berbasis proyek dan penggunaan Canva dalam meningkatkan kemampuan dan motivasi menulis kartu ucapan bagi siswa kelas VIIIE di SMPN 1 Terbanggi Besar. Peneliti berharap hasil penelitian ini memberikan kontribusi terhadap teori-teori pengajaran khususnya menulis kartu ucapan, memperkaya strategi guru dalam meenyelesaikan masalah-masalah ketika mengajar keterampilan menulis Bahasa Inggris dan menjadi referensi bagi peneliti-peneliti berikutnya yang juga tertarik untuk melaksanakan penelitian serupa.

\section{B. Metode}

Rancangan penelitian ini adalah penelitian tindakan kelas (classroom action research) dengan mengadaptasi tahapan penelitian tindakan kelas yang di kemukakan oleh Kemmis dan Mc Taggart (2008) seperti yang tercantum dalam Burns (2010). Model ini mencakup empat tahapan 
penelitian yaitu perencanaan (planning), tindakan/pelaksanaan (action), observasi (observing), dan refleksi (reflection).

Subjek pada penelitian ini adalah siswa kelas VIIIE SMPN 1 Terbanggi Besar pada semester ganjil tahun ajaran 2019/2020 yang terdiri dari 10 siswa laki-laki dan 20 siswa perempuan. Dalam melaksanakan penelitian ini, peneliti dibantu oleh seorang guru Bahasa Inggris sebagai kolaborator yang juga guru di SMPN 1 Terbanggi Besar.

Penelitian dilaksanakan dengan diawali penelitian pendahuluan. Pada tahap ini peneliti dan guru kolaborator mengumpulkan data hasil menulis kartu ucapan yang telah dilakukan oleh siswa sebelumnya. Kemudian guru mengoreksi dan memetakan masalah-masalah yang terjadi ketika siswa menulis. Peneliti memberikan kuesioner kepada siswa untuk mengetahui pendapat siswa tentang menulis. Kuesioner terdiri dari beberapa pernyataan, siswa diminta mengisinya dengan memberikan tanda cawang (ceklis) pada salah satu kriteria yaitu sangat setuju, setuju, biasa saja, tidak setuju, dan sangat tidak setuju. Rentang nilai untuk kriteria tersebut adalah dari 5 sampai 1 . Setelah itu, peneliti melaksanakan tahapan untuk siklus I penelitian yang terdiri dari dua kali pertemuan dan dilanjutkan dengan Siklus II yang terdiri dari tiga kali pertemuan.

Instrumen pengumpulan data pada penelitian ada tiga yaitu tes menulis berupa proyek menulis kartu ucapan, kuesioner dan lembar observasi. Hasil menulis siswa dikoreksi dengan menggunakan rubrik penilaian yang telah disusun oleh peneliti sebagai penilai pertama dan guru kolaborator sebagai penilai kedua. Observasi dilakukan setiap pertemuan dengan menggunakan lembar observasi baik oleh peneliti maupun guru kolaborator, hasilnya digunakan sebagai masukan bagi peneliti tentang kegiatan penelitian yang dilaksanakan di setiap siklus sedangkan kuesioner diberikan pada penelitian pendahuluan, di akhir siklus I dan siklus II untuk mengukur tingkat motivasi siswa berdasarkan pendapat siswa sebelum dan sesudah penelitian. Peningkatan kemampuan menulis siswa diukur berdasarkan hasil menulis siswa. 
Kriteria kesuksesan dibuat guna mengukur tingkat keberhasilan setiap siklus penelitian. Dengan berbagai pertimbangan peneliti membuat kriteria kesuksesan seperti terlihat pada Tabel 1.

Tabel 1: Kriteria Kesuksesan Penelitian

\begin{tabular}{|c|c|c|c|}
\hline No & Kriteria Kesuksesan & Sumber Data & Instrumen \\
\hline 1 & $\begin{array}{l}\text { Jumlah siswa yang } \\
\text { mendapatkan nilai } 65 \text { atau } \\
\text { lebih minimal } 65\end{array}$ & Hasil proyek siswa & $\begin{array}{l}\text { Tugas menulis } \\
\text { (membuat } \\
\text { kartu ucapan) }\end{array}$ \\
\hline 2 & $\begin{array}{l}\text { Rata-rata nilai seluruh } \\
\text { siswa sama atau lebih dari } \\
65 .\end{array}$ & Hasil proyek siswa & $\begin{array}{l}\text { Tugas menulis } \\
\text { (membuat } \\
\text { kartu ucapan) }\end{array}$ \\
\hline 3 & $\begin{array}{l}\text { Rata-rata nilai motivasi } \\
\text { siswa sama atau lebih dari } \\
65\end{array}$ & Pendapat siswa & Kuesioner \\
\hline
\end{tabular}

Peneliti menyusun prosedur atau tahapan pelaksanaan penelitian peningkatan kemampuan dan motivasi menulis melalui pembelajaran berbasis proyek dan penggunaan Canva seperti pada gambar 1 berikut.

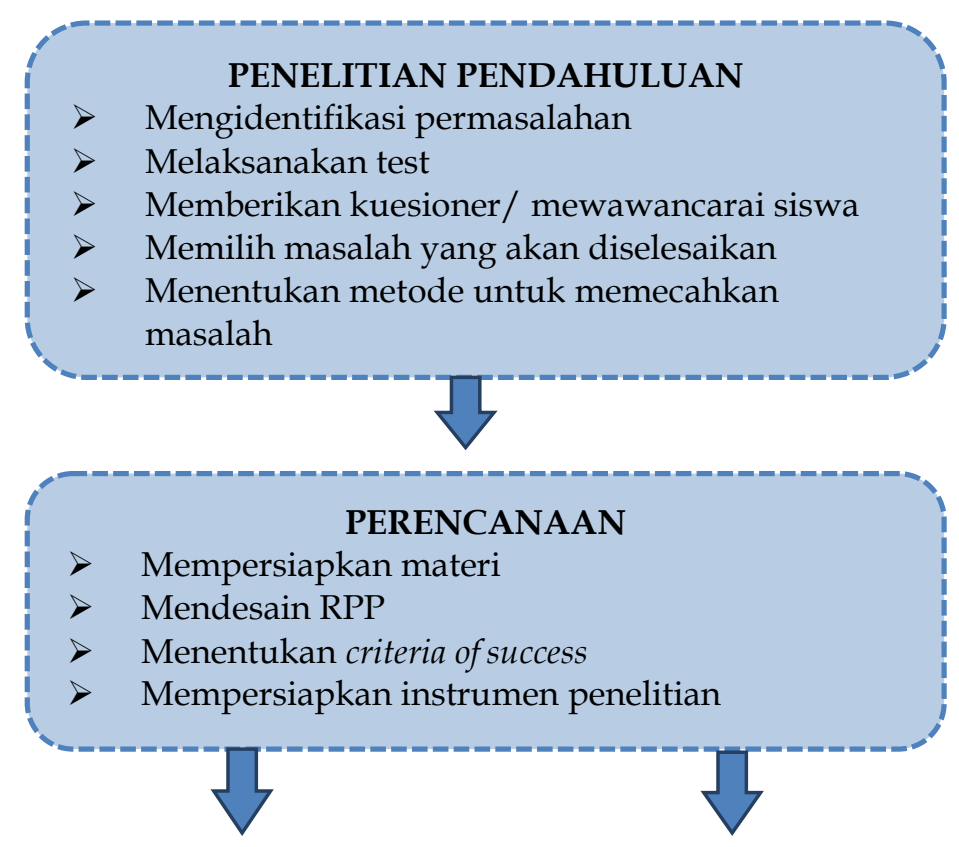




\section{Siswanjaya}

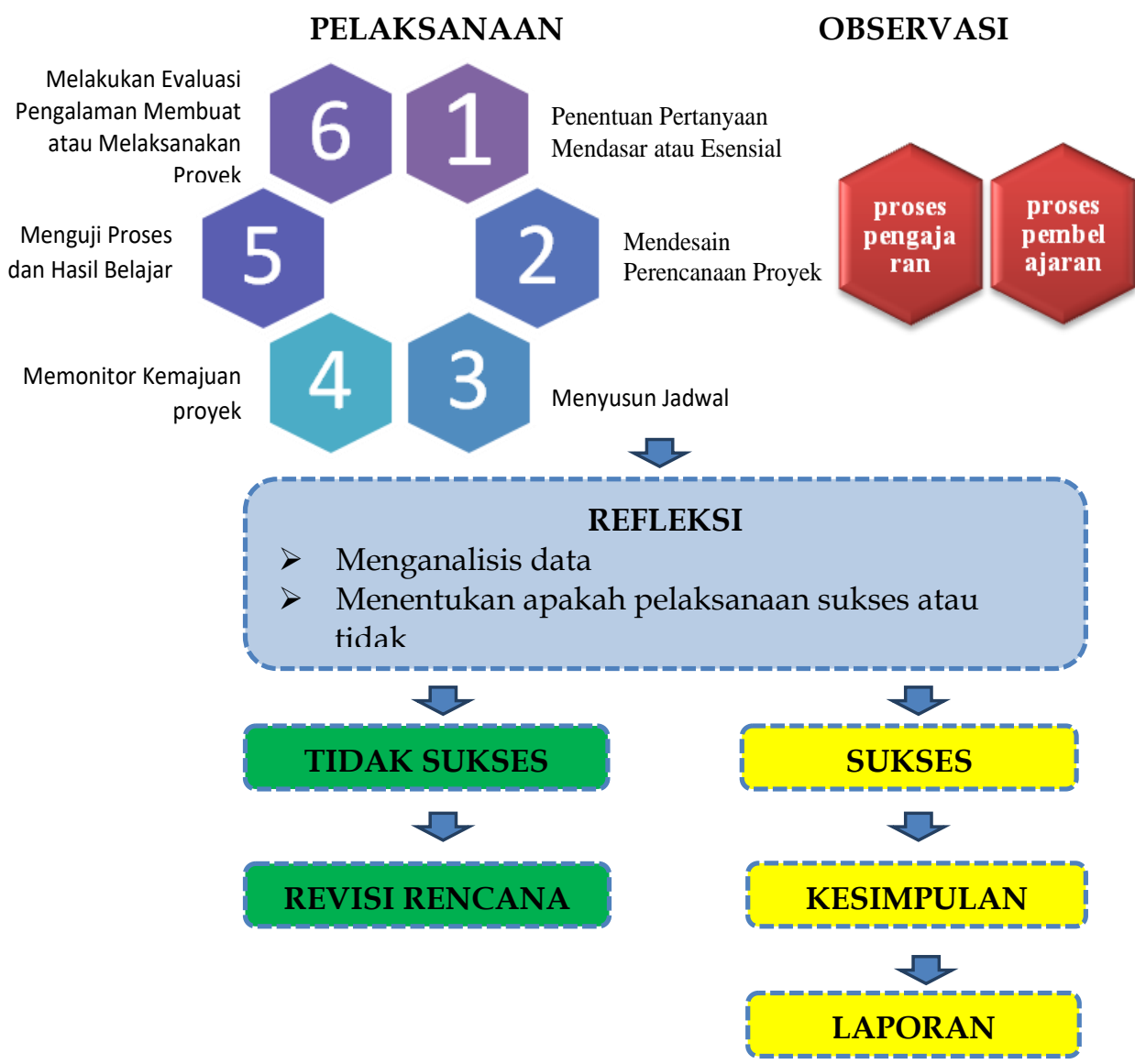

\section{Hasil dan Pembahasan}

Penerapan pembelajaran berbasis proyek dan penggunaan Canva dalam penelitian ini dilaksanakan dalam empat tahapan penelitian tindakan kelas yaitu perencanaan, pelaksanaan, observasi dan refleksi. Data awal diperoleh melalui penelitian pendahuluan yang dilakukan oleh peneliti sebelum melaksanakan penelitian. Data yang terkumpul di akhir setiap siklus menjadi bahan refleksi dan penentuan keberhasilan penelitian.

\section{Hasil}

Data kemampuan menulis siswa didapatkan melalui hasil menulis siswa yang dikoreksi baik oleh peneliti maupun guru kolaborator. Peneliti dan guru kolaborator menilai tiga aspek menulis yaitu: isi, bahasa dan 
kosakata, serta desain dan mekanik. Kriteria penilaian ketiga aspek menulis tersebut telah dijabarkan dalam rubrik penilaian yang disusun sebelum penelitian. Adapun hasil menulis pada penelitian pendahuluan dan siklus 1 terlihat pada tabel 2 berikut ini.

Tabel 2: Hasil Penilaian Menulis pada Penelitian Pendahuluan dan Siklus 1

\begin{tabular}{|c|c|c|c|c|c|c|c|c|}
\hline \multirow{3}{*}{ Kriteria Nilai } & \multicolumn{6}{|c|}{ Aspek Menulis } & \multirow{2}{*}{\multicolumn{2}{|c|}{ Nilai akhir }} \\
\hline & \multicolumn{2}{|c|}{ Isi } & \multicolumn{2}{|c|}{$\begin{array}{l}\text { Bahasa \& } \\
\text { Kosakata }\end{array}$} & \multicolumn{2}{|c|}{$\begin{array}{l}\text { Desain \& } \\
\text { Mekanik }\end{array}$} & & \\
\hline & PP & SI & PP & S1 & PP & S1 & PP & S1 \\
\hline Nilai Tertinggi & 100 & 100 & 80 & 80 & 60 & 100 & 80 & 80,7 \\
\hline Nilai Terendah & 40 & 60 & 40 & 60 & 20 & 60 & 40 & 60 \\
\hline Rata-Rata & 62 & 68 & 62 & 70 & 46 & 70 & 56.7 & 69,3 \\
\hline
\end{tabular}

Keterangan: PP= Penelitian Pendahuluan, S1=Siklus I

Berdasarkan tabel 2 di atas dapat dilihat hasil menulis siswa pada penelitian pendahuluan untuk aspek isi nilai tertinggi yang diperoleh siswa selaku subjek penelitian adalah 100, sedangkan nilai terendahnya adalah 40 . Nilai rata-rata seluruh subjek penelitian untuk aspek isi adalah 62 .

Pada aspek bahasa dan kosakata, nilai tertinggi yang diperoleh siswa adalah 80 sedangkan nilai terendahnya adalah 20. Nilai rata-rata seluruh subjek penelitian untuk aspek bahasa dan kosakata adalah 62 . Sementara pada aspek desain dan mekanik, nilai tertinggi yang diperoleh siswa adalah 60 sedangkan nilai terendahnya adalah 20. Nilai rata-rata seluruh subjek penelitian untuk aspek desain dan mekanik adalah 46 . Nilai akhir tertinggi dari kegiatan menulis tersebut adalah 80 dan nilai akhir terendah siswa adalah 40. Rata-rata nilai akhir siswa sebagai subjek penelitian pada penelitian pendahuluan adalah 56,7 .

Dari tabel di atas juga dapat dilihat kenaikan hasil menulis siswa pada Siklus I dibandingkan dengan hasil pada prapenelitian. Terjadi kenaikan pada rata-rata aspek menulis. Pada aspek isi terjadi kenaikan nilai rata-rata dari 62 menjadi 68, pada aspek bahasa dan kosakata terjadi kenaikan dari 62 menjadi 70 dan pada aspek desain dan mekanik terjadi 
kenaikan dari 46 menjadi 70. Kenaikan juga terjadi pada rata-rata nilai akhir siswa. Pada pra-penelitian rata-rata nilai akhir menulis siswa adalah 56,7 sedangkan pada siklus 1 adalah 69,3

Peneliti menghitung persentase hasil menulis pada penelitian pendahuluan dan siklus I berdasarkan kriteria menulis yang ada pada rubrik penilaian. Hasil tersebut dapat dilihat pada tabel 3 berikut.

Tabel 3: Persentase Hasil Menulis pada Penelitian Pendahuluan dan Siklus 1

\begin{tabular}{ccccccc}
\hline No & Kriteria & $\begin{array}{c}\text { Rentang } \\
\text { Nilai }\end{array}$ & $\begin{array}{c}\text { Penelitian } \\
\text { Pendahuluan }\end{array}$ & \multicolumn{2}{c}{ Siklus 1 } \\
\cline { 4 - 7 } & & & $\begin{array}{c}\text { Jumlah } \\
\text { Siswa }\end{array}$ & Persentase & $\begin{array}{c}\text { Jumlah } \\
\text { Siswa }\end{array}$ & Persentase \\
\hline $\mathbf{1}$ & Sangat baik & $89-100$ & 0 & $0 \%$ & 0 & $0 \%$ \\
\hline $\mathbf{2}$ & Baik & $77-88$ & 2 & $6.67 \%$ & 7 & $23.33 \%$ \\
\hline $\mathbf{3}$ & Cukup & $65-76$ & 8 & $26.67 \%$ & 12 & $40 \%$ \\
\hline $\mathbf{4}$ & Kurang & $>65$ & 20 & $66.67 \%$ & 11 & $36.67 \%$ \\
\hline & Dari tabel di atas dapat dilihat bahwa jumlah siswa yang masuk
\end{tabular}
kriteria cukup hingga sangat baik dari hasil menulis ada 10 siswa (33.33\%) dipenelitian pendahuluan sedangkan pada siklus 1 terdapat 19 siswa (63.33\%). Ini menandakan adanya peningkatan hasil menulis siswa ke arah yang lebih baik.

Data tingkat motivasi belajar siswa pada penelitian ini didapat dari hasil kuesioner yang diisi oleh siswa. Data tingkat motivasi siswa pada penelitian pendahuluan dan siklus I dapat dilihat pada gambar 1 berikut. 


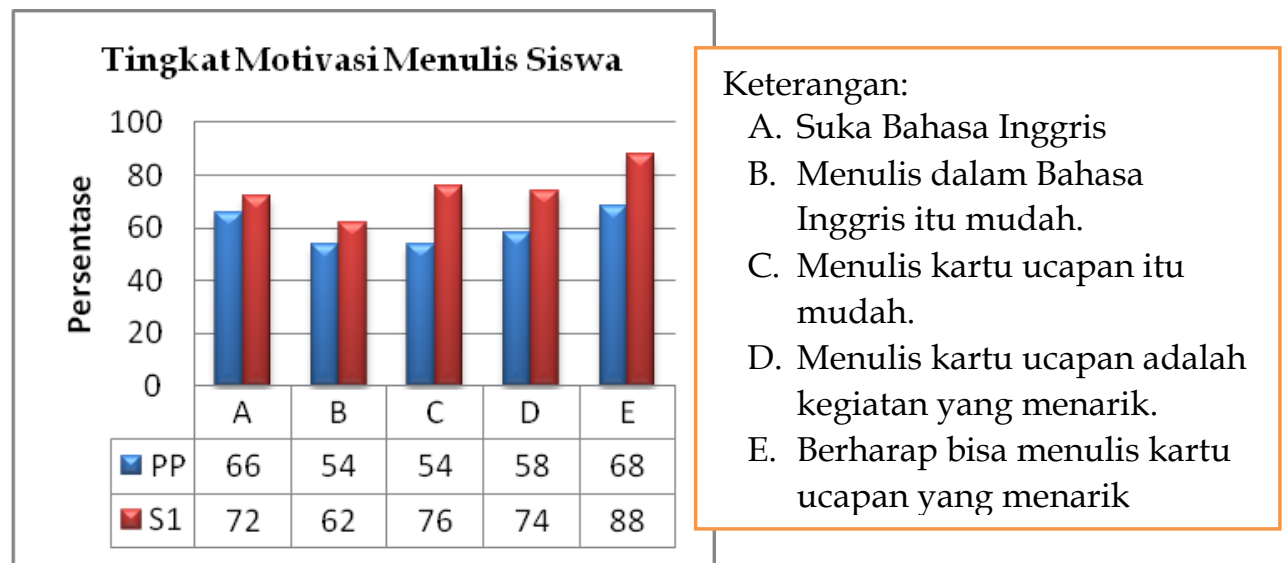

Keterangan: $\mathrm{PP}=$ Penelitian Pendahuluan, $\mathrm{S} 1=$ Siklus 1

Gambar 1. Hasil Kuesioner yang Mengukur Tingkat Motivasi Menulis Siswa pada Penelitian Pendahuluan dan Siklus 1

Dari hasil kuesioner yang diisi oleh siswa pada penelitian pendahuluan terdapat lima pernyataan yang mengukur tingkat motivasi siswa. Terjadi peningkatan yang positif terhadap masing-masing penyataan dari hasil pada penelitian pendahuluan ke siklus I dan ke Siklus II. Nilai rata-rata kelima pernyataan tersebut adalah $59.9 \%$ pada penelitian pendahuluan dan meningkat menjadi $74.4 \%$ pada siklus 1 .

Berdasarkan hasil observasi yang dilakukan oleh peneliti maupun guru kolaborator selama kegiatan di siklus 1, peneliti menyadari ada beberapa kelebihan dan kekurangan selama pelaksanaan siklus 1. Peneliti merasa puas karena penerapan pembelajaran berbasis proyek berjalan dengan baik, terjadi kerja sama yang baik antara peneliti, guru kolaborator dan siswa untuk mencapai tujuan pembelajaran. Dalam hal penggunaan media Canva siswa terlihat sangat antusias dan tertarik. Namun ada beberapa kelemahan yang terjadi seperti kurang kontrolnya guru terhadap setiap detail kegiatan pembelajaran sehingga guru tidak dapat memastikan apakah siswa benar-benar telah memahami materi dengan baik. Kelemahan lainnya terjadi pada pengorganisasian waktu 
yang terkesan kurang baik dalam hal guru dan siswa melakukan pembelajaran maupun saat mengerjakan proyek menggunakan Canva.

Setelah melalui tahapan refleksi, peneliti memutuskan untuk melanjutkan penelitian ke siklus berikutnya dengan pertimbangan hasil penelitian ini belum memenuhi salah satu kriteria kesusksesan yang telah ditetapkan yaitu jumlah siswa yang memperoleh nilai sama atau lebih dari 65 harus sebanyak $65 \%$ dari jumlah subjek penelitian.

Pada siklus II peneliti menambah jumlah pertemuan menjadi 3 kali pertemuan dan peneliti juga lebih fokus pada pemberian materi dan contohcontohnya. Hasil kemampuan menulis siswa pada siklus II dibandingkan dengan hasil pada siklus I dapat dilihat pada tabel 3 berikut.

Tabel 3. Hasil Menulis Siswa pada Siklus I dan Siklus II

\begin{tabular}{lcccccccc}
\hline & \multicolumn{7}{c}{ Aspek Menulis } \\
\cline { 2 - 8 } Kriteria Nilai & \multicolumn{3}{c}{ Isi } & \multicolumn{1}{c}{$\begin{array}{c}\text { Bahasa \& } \\
\text { Kosakata }\end{array}$} & $\begin{array}{c}\text { Desain \& } \\
\text { Mekanik }\end{array}$ & Nilai akhir \\
\cline { 2 - 8 } & S1 & S2 & S1 & S2 & S1 & S2 & S1 & S2 \\
\hline Nilai Tertinggi & 100 & 100 & 80 & 100 & 100 & 100 & 80,7 & 100 \\
\hline Nilai Terendah & 60 & 60 & 60 & 60 & 60 & 60 & 60 & 60 \\
\hline Rata-Rata & 68 & 76 & 70 & 74 & 70 & 90 & 69,3 & 79,6 \\
\hline
\end{tabular}

Keterangan: S1=Siklus I, S2=Siklus II

Berdasarkan Tabel 1.3 di atas dapat dilihat rata-rata nilai meelis siswa pada setiap aspek mengalami peningkatan. Pada aspek isi terjadi peningkatan nilai rata-rata dari 68 pada siklus I menjadi 76 pada siklus II, pada aspek bahasa dan kosakata juga mengalami peningkatan dari 70 pada siklus I menjadi 74 dan pada aspek desain dan mekanik juga mengalami peningkatan dari 70 pada siklus I menjadi 90 pada siklus II.

Peningkatan setiap aspek menulis berbangding lurus dengan peningkatan pada rata-rata nilai akhir siswa. Pada siklus I rata-rata nilai akhir siswa adalah 69,3 meningkat menjadi 79,6. 
Persentase jumlah siswa terhadap kriteria menulis pada siklus II juga mengalami peningkatan. Data peningkatan tersebut dapat dilihat pada tabel 4 berikut.

Tabel 4. Persentase Hasil Menulis pada Siklus I dan Siklus II

\begin{tabular}{|c|c|c|c|c|c|c|}
\hline \multirow[b]{2}{*}{ No } & \multirow[b]{2}{*}{ Kriteria } & \multirow{2}{*}{$\begin{array}{c}\text { Rentang } \\
\text { Nilai }\end{array}$} & \multicolumn{2}{|c|}{ Siklus I } & \multicolumn{2}{|c|}{ Siklus II } \\
\hline & & & $\begin{array}{c}\text { Jumlah } \\
\text { Siswa }\end{array}$ & Persentase & $\begin{array}{c}\text { Jumlah } \\
\text { Siswa }\end{array}$ & Persentase \\
\hline 1 & Sangat baik & $89-100$ & 0 & $0 \%$ & 4 & $13.33 \%$ \\
\hline 2 & Baik & $77-88$ & 7 & $23.33 \%$ & 15 & $50 \%$ \\
\hline 3 & Cukup & $65-76$ & 12 & $40 \%$ & 9 & $30 \%$ \\
\hline 4 & Kurang & $>65$ & 11 & $36.67 \%$ & 2 & $6.67 \%$ \\
\hline
\end{tabular}

Dari Tabel 4 di atas dapat dilihat bahwa jumlah siswa yang masuk kriteria cukup hingga sangat baik terjadi peningkatan dari 19 siswa (63.33\%) pada siklus I menjadi 28 siswa (93.33) pada siklus II.

Dari hasil kuesioner yang diisi oleh siswa pada siklus II ini diketahui bahwa tingkat motivasi menulis siswa. Terjadi peningkatan yang positif terhadap motivasi siswa pada siklus II ini. Peningkatan tersebut dapat dilihat pada gambar 2 berikut.

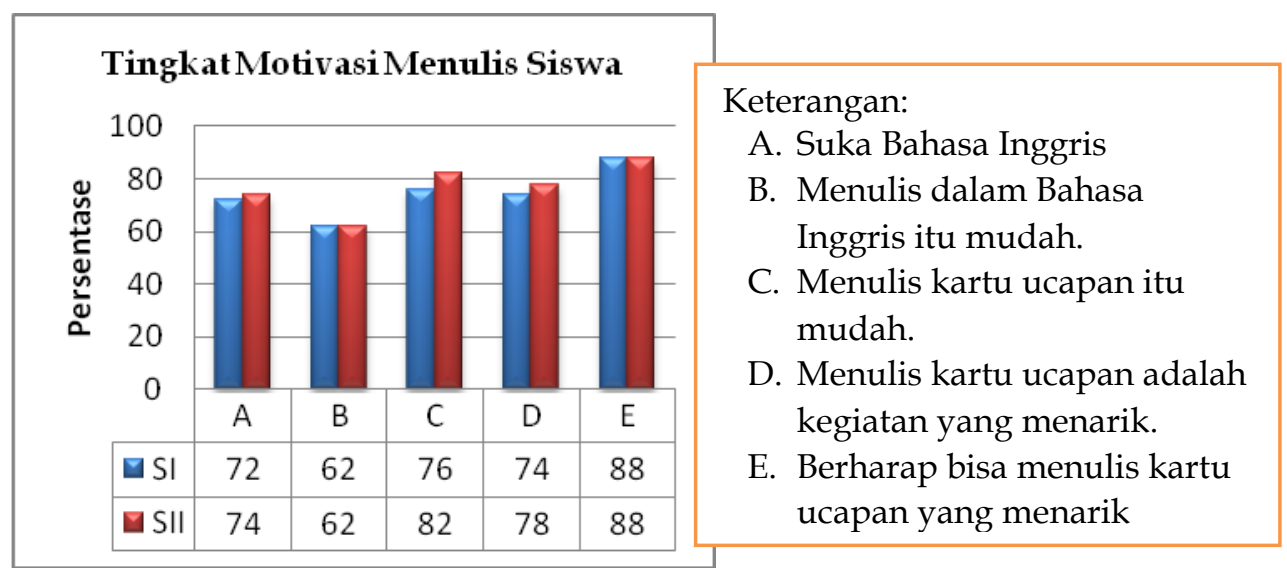

Keterangan: SI = Siklus I, SII = Siklus II 
Gambar 2. Hasil Kuesioner yang Mengukur Tingkat Motivasi Menulis Siswa pada Siklus I dan Siklus II.

Dari gambar 2 tersebut dapat dilihat bahwa terjadi peningkatan nilai rata-rata dari kelima pernyataan diatas. Hasil pada siklus I adalah 74.4\%. Hasil ini meningkat menjadi $77.1 \%$ pada siklus II.

Pada siklus II ini peneliti sudah dapat mengatasi masalah-masalah yang terjadi pada siklus I seperti kurang pahamnya siswa tentang kartu ucapan, kurang pahamnya siswa bagaimana menggunakan Canva, kurang kontrolnya peneliti dan guru koordinator terhadap setiap kegiatan siswa dan kurang baiknya pengorganisasian waktu yang ada. Hasil dari Siklus II juga sudah memenuhi ketiga kriteria kesuksesan yang sudah ditentukan oleh peneliti. Oleh karena itu, peneliti merasa penelitian ini sudah berhasil dan tidak perlu melanjutkan ke siklus berikutnya.

\section{Pembahasan}

Pada penelitian ini peneliti fokus pada peningkatan keterampilan dan motivasi menulis siswa. Data yang diperoleh dari hasil menulis dan kuesioner yang dikerjakan siswa pada penelitian ini dapat dilihat pada tabel 5 berikut.

Tabel 5 Nilai Rata-Rata Motivasi dan Keterampilan Menulis

\begin{tabular}{ccccc}
\hline \multirow{2}{*}{ No } & Aspek Penilaian & $\begin{array}{c}\text { Nenelitian } \\
\text { Pendahuluan }\end{array}$ & Siklus I & $\begin{array}{c}\text { Siklus } \\
\text { II }\end{array}$ \\
\cline { 3 - 5 } & Motivasi & 59.9 & 74.1 & 84.9 \\
\hline $\mathbf{2}$ & $\begin{array}{c}\text { Keterampilan } \\
\text { Menulis }\end{array}$ & 56.7 & 69.3 & 79.6 \\
\hline
\end{tabular}

Pada tabel di atas dapat dilihat terjadi peningkatan nilai motivasi siswa dan keterampilan menulis dari penelitian pendahuluan ke Siklus I dan ke Siklus II. Hal ini membuktikan bahwa PjBL dan Canva memberi 
pengaruh yang positif untuk peningkatan motivasi dan keterampilan menulis siswa.

Pembelajaran berbasis proyek mempunyai potensi meningkatkan kemampuan siswa dalam menulis. Setiap tahapan pembelajaran yang dilalui dalam PjBL memberikan kesempatan pada siswa untuk memahami materi dengan baik, mempersiapkan proyek yang akan dikerjakan lebih terstruktur dalam hal perencanaan maupun penyusunan jadwal. Penggunaan Canva juga membantu siswa memperkaya pemahaman mereka akan materi karena Canva menyediakan berbagai contoh-contoh kartu ucapan yang bisa dipelajari siswa karena contohcontoh tersebut memberikan masukan bagi siswa.

Hasil proyek yang dikerjakan oleh siswa dapat dilihat bahwa terjadi peningkatan disemua aspek menulis baik isi, bahasa dan kosakata maupun desain dan mekanik. Hal ini sejalan dengan hasil penelitian Wibowo, Y.P Aji, K. R (2017) yang menyatakan bahwa terjadi peningkatan kemampuan siswa dalam menulis kartu ucapan. Peningkatan tersebut terjadi dalam hal kreativitas siswa dalam mendesain kartu ucapan.

Pada aspek isi PjBL memberikan kesempatan lebih kepada siswa untuk memahami banyak tentang kartu ucapan. Hal ini terjadi saat guru menjelaskan materi, saat siswa memahami contoh-contoh kartu ucapan pada sumber lain dan juga saat guru memberikan pertanyaan-pertanyaan mendasar yang mengarahkan siswa dalam membuat proyek.

Canva juga memiliki peranan dalam peningkatan aspek isi saat siswa membuat kartu ucapan. Hal ini disebabkan siswa diberi kesempatan untuk membaca contoh-contoh kartu ucapan yang banyak tersedia di canva. Hal tersebut tidak menutup kemungkinan siswa untuk menggunakan ungkapan-ungkapan yang sama saat mereka membuat kartu undangan.

Pada aspek bahasa dan kosakata juga terjadi peningkatan yang tidak bisa dipungkiri karena penerapan PjBL dan penggunaan Canva. PjBL memberi kesempatan kepada siswa untuk bekerja dalam kelompok 
sehingga siswa dapat saling bertukar informasi dan saling memberi masukan. Hal yang paling utama adalah karena siswa membaca contohcontoh pada Canva, bagaimana kata-kata ditulis, bagaimana frase dan kalimat dibentuk.

Pada aspek desain dan mekanik terjadi peningkatan yang signifikan. Pengorganisasian waktu yang cukup pada PjBL memberikan siswa keleluasaan untuk menyelesaikan proyek mereka. Mengerjakan setiap detail proyek mereka dengan seksamana. Kemudahan yang ditawarkan oleh Canva dengan penyediaan template kartu ucapan juga menjadi faktor terjadinya peningkatan kualitas kartu ucapan dari aspek desain dan mekanik. Siswa dapat dengan mudah memilih template, mengubah ukuran tulisan, mengombinasikan warna, memasukkan gambar, dan lain sebagainya. Hal ini juga mendukung hasil penelitian dari Yundayani dkk. (2019) yang mengatakan bahwa Canva menawarkan keuntungan yang besar dalam meningkatkan keterampilan menulis karena Canva menyediakan gambar, warna, foto, ukuran huruf, dan grafik yang membantu mereka mengembangkan ide sehingga mereka bisa lebih kreatif. Hardiyanto (2019) dalam hasil penelitiannya juga menyimpulkan bahwa terjadi respon yang baik pada setiap tahapan PjBL yang dilalui siswa dalam pembelajaran. Dari hasil penelitian ini juga dapat dilihat terjadi peningkatan pada aspek content, organization, grammar, vocabulary, mechanics, dan panjang tulisan. Ditemukan juga bukti bahwaimplementasian PjBL ini juga menyenangkan, mempromosikan pembelajaran kolaboratif, dan layak dilakukan.

Motivasi menjadi salah satu faktor penting dalam kegiatan belajar mengajar. Motivasi dapat dari dalam diri siswa sendiri maupun dari faktor luar siswa. Motivasi yang berasal dari dalam merupakan faktor paling penting yang akan mendukung proses pembelajaran. Hasil penelitian menunjukkan tingkat motivasi siswa yang menjadi lebih baik dari penelitian pendahuluan ke Siklus I dan ke Siklus II Hasil ini mendukung temuan Yundayani dkk. (2019) yang mengatakan 
penggunaan Canva memotivasi siswa dan mengurangi kekhawatiran dalam menulis. Ini juga sesuai dengan hasil penelitian Anggara (2017) yang mengatakan pembelajaran berbasis proyek memotivasi siswa-siswa dalam kegiatan pembelajaran. Selain penggunaan Canva, penerapan pembelajaran berbasis proyek juga memberi dampak pada tingkat motivasi siswa. Hal ini sejalan dengan Insyaska (2015) dan Nicodemus (2017) yang menyatakan bahwa penerapan strategi pembelajaran berbasis proyek memiliki pengaruh terhadap motivasi belajar siswa sehingga meningkat lebih tinggi.

\section{Penutup}

Kesimpulan hasil penelitian tindakan kelas adalah motivasi dan keterampilan menulis siswa yang rendah dapat ditingkatkan dengan penggunaan Canva pada pembelajaran berbasis projek. Peningkatan motivasi siswa ditunjukkan oleh peningkatan nilai kuesioner yang diisi oleh siswa, sedangkan peningkatan keterampilan menulis siswa ditunjukkan oleh peningkatan hasil menulis siswa baik pada aspek isi, bahasa dan kosakata serta desain dan mekanik.

\section{Ucapan Terima Kasih}

Peneliti menyampaikan terimakasih yang sebesar-besarnya kepada berbagai pihak yang telah membantu penyelesaian penelitian tindakan kelas ini yaitu (a) Kepala SMPN 1 Terbanggi Besar yang telah memberikan izin untuk melaksanakan penelitian tindakan kelas ini; (b) Guru kolaborator, guru-guru dan staff SMPN 1 Terbanggi Besar yang telah membantu berbagai hal dari persiapan hingga akhir dari penelitian ini; (c) Ketua MGMP Bahasa Inggris SMP Lampung Tengah dan pengurus yang telah memfasilitasi seminar penelitian tindakan kelas ini dalam pertemuan MGMP; dan (d) Bapak Ridwan, S.Pd., yang telah memberikan banyak informasi dan motivasi kepada saya dalam proses penyelesaian penelitian tindakan kelas ini. 


\section{Daftar Referensi}

Anggara, S.A. (2017). Penerapan Model Project Based Learning untuk Meningkatkan Kemampuan Menulis Siswa. Journal of Arabic Studies, 2 (2), 2017, 186-196 DOI: http://dx.doi.org/10.24865/ajas.v2i2.57

Blumenfeld, et al. (1991). Educational Psychologist: Motivating Project Based Learning: Sustaining the Doing, Supporting the Learning. Lawrence: Erlbaum Assosaites, Inc

Brown, H. D \& Lee, H. (2015). Teaching by Princeples: An Interactive Approach to Languange Pedagogy. New York: Pearson Education, Inc.

Burn, A. (2010). Doing Action Research in English Language Teaching: A Guide for Practicioners. New York: Routledge 270 Madison Ave

Cipta.

Dimyati dan Mudjiono.(2009). Belajar dan Pembelajaran. Jakarta: Rineka

Grenville, Kate. (2001). Writing from Start to Finish: A Six Step Guides. Australia: Allen and Unwin.

Hamalik, O. (2008). Proses Belajar Mengajar.Jakarta: Bumi Aksara

Hardiyanto. (2019). The Implementation of Project-Based Learning in Teaching Writing of Factual Report Texts. http://digilib.unila.ac.id. Retrieved on October 5th, 2019.

Harmer, J. (2004). How to Teach. England: Pearson Education.

Harmer, Jeremy. (2001). The practice of English Language teaching 3rd Ed. Longman: Pearson Education.

Hidayat, R.W. (2020). Peningkatan motivasi dan hasil belajar peserta Didik Pada Pembelajaran Comparison Degree melalui lingkar tiga warna. Jurnal Didaktika Pendidikan Dasar 4(1) 255-270. doi: 10.26811/didaktika.v4i1.155

Insyasika, D. (2015). Pengaruh Project Based Learning terhadap Motivasi Belajar, Kreativitas, Kemampuan Berpikir Kritis, dan Kemampuan Kognitif Siswa pada Pembelajaran Biologi. Pendidikan Biologi. Pascasarjana. Universitas Negeri Malang.

Kemendikbud. (2018). Materi Bimbingan Teknis Fasilitator dan Instruktur Kurikulum 2013 Tahun 2018. Modul. Tidak diterbitkan. 
Larmer, John et al. (2015). Setting the Standard for Project Based Learning. Alexandria: ASCD

Nicodemus, A. (2017). Penerapan Model Pembelajaran Project Based Learning untuk Meningkatkan Motivasi dan Prestasi Belajar Siswa Sekolah Menengah Kejuruan pada Mata Pelajaran Menggambar Dengan Perangkat Lunak. Skripsi, Jurusan Teknik Sipil, Fakultas Teknik, Universitas Negeri Malang

Nunan, D. (2003). Practical English Language Teaching. Singapore: Mc GrawHill Company White, Fred D.1986. The Writer Art. California: Wadsworth Publising Company

Pratomo, B. (2014). The Use of Project-Based Learning to Improve the Students' Writing Skills at Class VII F of SMPN 7 Magelang in the Academic Year of 2013/2014. Retrieved on October 1st, 2019.

Raimes, A. (1983). Technique in Teaching Writing. New York: Oxford University Press.

Smaldino, S. E., Lowther, D. L., Mims, C., \& Russell, J. D. (2015). Instructional Technology and Media for Learning. NY: Pearson.

Wibowo, Y.P \& Adi, K.R. (2017). Proceeding : Using Project-Based Learning to Improve Students' Writing on Greeting Card. Semarang. The $2^{\text {nd }}$ TEYLIN International Conference: https://eprints.umk.ac.id Retrieved on October $5^{\text {th }}, 2019$.

Yundayani, A., Susilawati, S., \& Chairunnisa, C. (2019). Investigating the effect of Canva on students' writing skills. English Review: Journal of English Education, 7(2), 169-176. doi: 10.25134/erjee.v7i2.1800. 